\title{
Local management strategies and attitudes towards selected threatened or protected plant species in Limpopo Province, South Africa
}

\author{
MARULA TRIUMPH RASETHE ${ }^{1, \bullet}$, MARTIN POTGIETER $^{1}$, MICHÈLE PFAB ${ }^{2}$ \\ ${ }^{1}$ Department of Biodiversity, University of Limpopo. Private Bag X1106, Sovenga, 0727, South Africa. Tel: +27-767843608, \\ vemail: truimph.rasethe@gmail.com \\ ${ }^{2}$ Biodiversity Assessment and Monitoring, South African National Biodiversity Institute. Private Bag X101, Silverton, 0184, South African
}

Manuscript received: 10 June 2021. Revision accepted: 21 August 2021.

\begin{abstract}
Rasethe MT, Potgieter M, Pfab M. 2021. Local management strategies and attitudes towards selected threatened or protected plant species in Limpopo Province, South Africa. Biodiversitas 22: 3773-3784. Throughout South Africa, ordinary people are managing and using local natural resources in ways that enhance their lives, but there is a major concern about the sustainability of wild plant harvest. This study aims to investigate the current management strategies employed by local people in the Limpopo Province for selected threatened or protected plant species (TOPS). Semi-structured questionnaires were used to gather information from a total of 333 participants, i.e. 110 community members (CMs), 180 traditional health practitioners (THPs), and 28 traditional leaders (TLs), as well as from 15 conservation officers (COs). The study area included the districts of Capricorn, Sekhukhune, Mopani, Vhembe, and Waterberg. Results indicated that in all districts of the province most CMs and THPs reported that no one managed plant resources in their surrounding communal lands, though TLs indicated that the state was involved with management. Fifty-nine percent of THPs indicated that there are no traditional rules that are applied towards conservation of communal lands, yet $91 \%$ of other participants in the Mopani, Sekhukhune, and Capricorn districts indicated that traditional rules are followed. Most CMs in these three districts were allowed to participate in conservation initiatives, although most of them did not know that the plants they were using were threatened and protected in legislation. It is recommended that collaborative partnerships be initiated between government and TLs in relation to managing the threatened or protected plant species in communal lands.
\end{abstract}

Keywords: Local conservation, management of plants, protected species, threatened species, TOPS-listed plants

\section{INTRODUCTION}

Throughout the world, many thousands of plant species make an important contribution to the life of local communities (FAO 2016). It is estimated that around one billion people use wild plants daily (Kaoma and Shackleton 2015), including threatened or protected plant species (TOPS), which are highly used in different parts of the world. In different parts of Africa, more than 5400 plant species are used medicinally (Van Wyk 2015). This high reliance is due to limited access to hospitals and other modern medical facilities (Monica et al. 2016).

There is a major concern in South Africa about the sustainability of wild plant harvest for traditional medicine. Thirty-one percent of South Africa's plant taxa are of conservation concern, $14.3 \%$ (2924 species) of which are threatened species, i.e. Critically Endangered Possible Extinct of 75 species, Critically Endangered of 404 species, Endangered of 886 species, Vulnerable of 1559 species; and $16.7 \%$ (3401 species) of conservation concern species, i.e. Near Threatened (547 species), Critically Rare of 166 species, Rare of 1246 species, Data Deficient of 414 species, and Data Deficient-T of 1028 (South African National Biodiversity Institute 2020). A lack of resource management combined with high demand has resulted in a significant decline in wild populations (Rasethe et al. 2013). According to Rankoana (2016), the management of traditional medicinal plant resources is the most complex resource management issue currently facing conservation agencies, traditional leaders, and resource users.

According to Rasethe et al. (2013), Rankoana (2016), Petersen et al. (2017) and van Wyk and Prinsloo (2018), local people in South Africa may employ simple, effective, and affordable measures to manage their natural resources such as local rules and taboos. The system of managing natural resources is termed a bottom-up approach, because locals control resources in their immediate vicinity. For example, in southern Africa, people in some rural villages are granted permission by chiefs and headmen to cut down or collect plants, and those who do not comply are fined a certain amount of money (Petersen et al. 2017). Rasethe et al. (2013) noted that in many rural areas people are not allowed by cultural restrictions to fell marula trees (Sclerocarya birrea) because of the tree's important traditional uses. According to Semenya and Mokgoebo (2020), there are taboos whereby certain resources in a community are not allowed to be used or harvested at certain times. For instance, felling trees is not allowed in graveyards because of the belief that they affect the soul of the deceased (Constant and Tshisikhawe 2018). Beliefs and taboos can also help in protecting plant resources from excessive use (Rankoana 2016). Stem bark is harvested for medicinal purposes on the eastern side of a tree, because of the belief that more healing is stored on this side of a tree (Monica et al. 2016), thereby preventing a plant from being ring-barked. However, bottom-up approach has its 
constraints that can lead to ineffective management of natural resources.

The use of state-implemented laws is another way of managing natural resources is called a top-down approach, because the government is viewed as controlling everything through legislation, and usually side-line the ideas of locals with respect to the management of their surrounding natural resources (Khadka and Vacik 2012). State agencies, however, claim that indigenous people regularly violate conservation laws, leading to the depletion of natural resources (Rasethe et al. 2013). This top-down system also results in disruption, because local communities have limited access to their surrounding natural resources. Khadka and Vacik (2012) reported that local people in Asia and southern Africa regularly complain about this approach, denying them access to natural plant resources such as firewood. A top-down approach often results in local communities being dissatisfied, consequently leading to the secret and illegal overexploitation of natural resources (Kangalawe et al. 2014). To avoid further loss due to ineffective management strategies, this study aims to investigate the current management strategies employed by local people for selected threatened or protected plant species in the Limpopo Province of South Africa.

\section{MATERIALS AND METHODS}

\section{Study area}

The study areas were located in the five districts of the Limpopo Province of South Africa, namely Capricorn, Mopani, Sekhukhune, Vhembe, and Waterberg districts (Figure 1). The Limpopo Province falls within the savanna biome, the vegetation comprising a combination of trees, shrubs, and grasses and characterized by a diverse flora with useful plant species that local people utilize to meet their livelihood needs (Mucina and Rutherford 2006).

\section{Threatened or protected plant species}

The study involved a total of six plant species that are threatened according to the criteria outlined by the South African Biodiversity Institute (2020). Furthermore, legally protected by regulations such as TOPS (Threatened or Protected Species), NFA (National Forestry Act) No. 84 of 1998, and LEMA (Limpopo Environmental Management Act) No. 7 of 2004) amongst others. The investigated threatened and protected species are also highly sought after by traditional healers and community members to treat different ailments and/or used for magical purposes (Table 1).

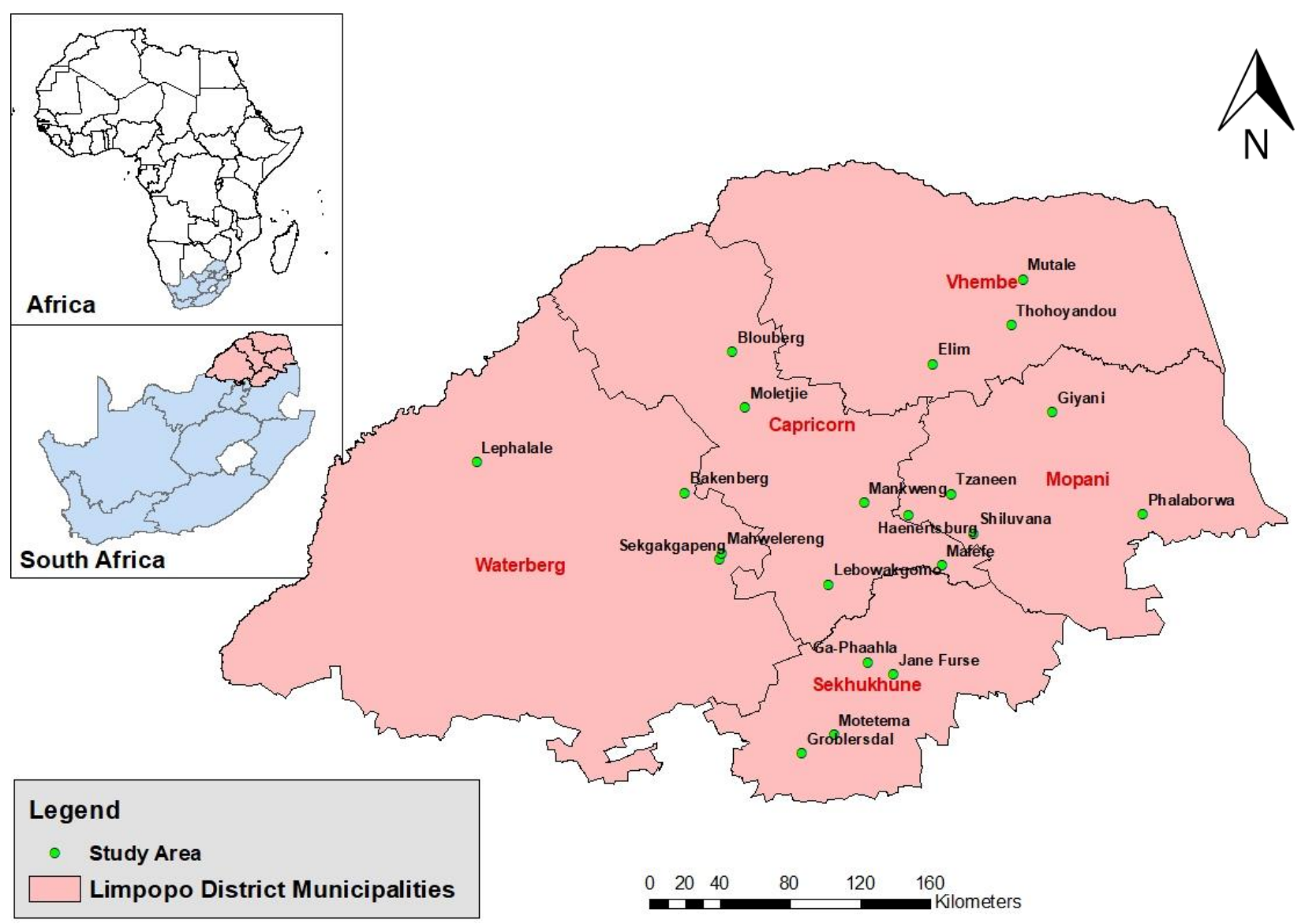

Figure 1. Study areas surveyed in the five districts of the Limpopo Province, South Africa 
Table 1. The use, distribution and conservation status of threatened or protected plants species in the current study




Table 2. Quantity of participants interviewed per district

\begin{tabular}{lcccccc}
\hline Groups & \multicolumn{3}{c}{ Districts } & Total \\
\cline { 2 - 6 } & Capricorn & Sekhukhune & Mopani & Waterberg & Vhembe & 20 \\
THPs & 40 & 40 & 40 & 40 & 25 & 10 \\
CMs & 25 & 25 & 25 & 6 & 4 & 110 \\
TLs & 6 & 6 & 6 & 3 & 3 & 10 \\
COs & 3 & 3 & 74 & 74 & 37 & 333 \\
Total & 74 & 74 & & 74 & 37 \\
\hline
\end{tabular}

\section{Data collection}

A reconnaissance field trip was conducted in March 2014 in the five districts of the Limpopo Province to explain the goals of the research project, to obtain permission to conduct this study within the areas, and also to meet with locals (traditional healers and community members) to request them to participate in the study. A criterion for selecting participants was random for community members and snowball for traditional healers with the help of local traditional leaders (Neto et al. 2010).

Formal surveys were done during the period JanuaryDecember 2015. Semi-structured questionnaires were used to gather information from community members (CM), traditional health practitioners (THP), traditional leaders (TL) (Chief or Induna), and conservation officers (CO) on current management practices, knowledge on legislations and protected plants, and recommended management strategies. This kind of questionnaire is an accurate, simple, efficient method, and a quick way to collect data for a large sample size (Gill et al. 2008). A total number of 333 participants were interviewed for the study (Table 2). Chief is a leader or ruler of a people or tribe or clan. Induna is a senior appointed by the king or chief, who often acts as a bridge between the people and the king or chief.

\section{Management of plants by lay people (Bottom-up approach)}

Participants were asked to disclose who manages plants in their communal lands. They were also asked to indicate local rules or rules given by the government, which are used to protect plant resources in their area. Participants who harvested from communal lands were asked if they need a permit to harvest. Participants were asked if they knew about environmental legislation such as NEM:BA (National Environmental Management: Biodiversity Act) No. 107 of 2004, TOPS (Threatened or Protected Species) Legislation, CITES (Convention on International Trade in Endangered Species) of Wild Fauna and Flora Legislation, NFA (National Forestry Act) No. 84 of 1998, and LEMA (Limpopo Environmental Management Act) No. 7 of 2004. Those who used the plants were further asked if they were aware that the plants they had been using are legislatively protected. The participants were further asked to gather information on future plans on protecting and managing the use of their plants. They were asked what they think should be changed and what they think should not be changed.

\section{Management of plants by conservation officials (top- down approach)}

Conservation officials (COs) were asked about the legislations they use to manage protected plants. Furthermore, asked about the methods used to implement the legislations in place. Problems encountered by COs when managing the protected plants were also documented.

\section{Ethical consideration}

Prior informed consent was obtained from the TLs, THPs, and CMs to conduct this study within their area of jurisdiction (Neto et al. 2010). Participants gave their informed consent for the publication of all results and any accompanying images, before commencing with the interview schedules as required by the University of Limpopo's ethics committee. Researchers also adhered to the ethical guidelines of the International Society of Ethnobiology (www.ethnobiology.net).

\section{Data analysis}

Information collected through a semi-structured questionnaire was tabulated into meaningful patterns and summarized using descriptive statistics such as frequencies and percentages using Microsoft Excel 2000. PérezVicente and Ruiz (2009) recommended. The majority of the data collected in this study were descriptive and qualitative, and therefore, were explained directly.

\section{RESULTS AND DISCUSSION}

\section{Management of plants by lay people (bottom-up approach)}

In all districts, most CMs and THPs indicated that no one managed plant resources in their surrounding communal lands. All CMs in the Waterberg and Vhembe districts stated that their communal lands are not managed at all, though a significant number of CMs and THPs in the remaining districts mentioned that the chief and/or induna are responsible for management in their areas (Figure 2). In these districts, some participants mentioned that the management of plants by the traditional leadership applies to all the plants, irrespective of their conservation status. Across all districts, participants indicated that the government had a minimal role to play in natural resource management. According to TLs, chiefs (69\%), indunas (54\%), and the government (31\%) are currently working together to manage plants in their communal lands. Only $8 \%$ of TLs mentioned the involvement of local people. 


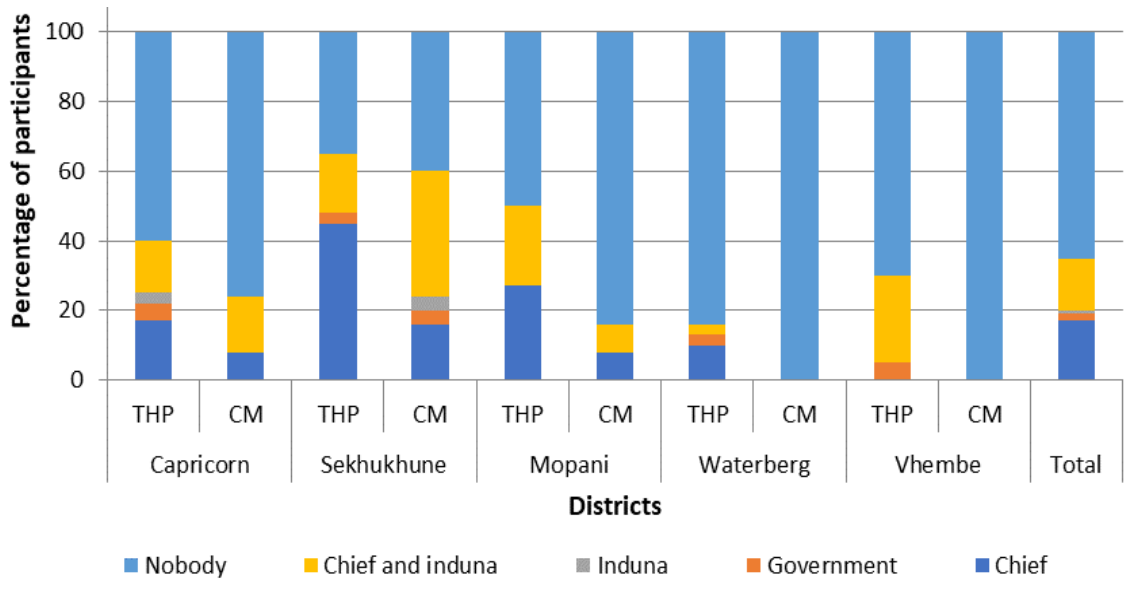

Figure 2. People responsible for the management of plants in communal lands of the Limpopo Province, South Africa, as according to traditional health practitioners (THPs) and community members (CMs)

Lack of plant resource management in communal areas declared by most CMs and THPs is contrary to the findings of different researchers in African countries, such as Tanzania (Kangalawe et al. 2014) and Kenya (Monica et al. 2016), who found that TLs are responsible for the management of plants in communal lands. The absence of management measures for plant resources in the communal lands of Limpopo Province needs to be addressed urgently. In KwaZulu-Natal, the lack of on-ground management has led to the local extinction of Warburgia salutaris (Coopoosamy and Naidoo 2012). This same species was also reported as being locally extinct in Zimbabwe, due to the absence of natural resource management in communal lands (Maroyi 2013).

The allusion by some CMs that chief and/or induna are responsible for the management of plants is not unexpected as it is commonly known amongst Black South Africans that TLs are responsible for the management and control of local natural resources (Rasethe et al. 2013; Rankoana 2016). The comprehensive management of plants by traditional leaders, irrespective of their conservation status creates some doubt about the capability of TLs in managing plant species that are protected by legislation, as they would require special management. The minimal role played by the government in natural resource management is concerning since the public sector includes qualified professionals in plant management and conservation. Furthermore, the lack of local people's involvement in the management of plant resources in the current study, is seen as a lost opportunity for raising awareness on the status of local species availability (Semenya and Mokgoebo 2020).

\section{The use of traditional rules as a management tool}

Forty-one percent of THPs indicated that traditional rules were implemented in their areas, whereas the existence of rules was mentioned by only $23 \%$ of CMs.
The majority of THPs (59\%) and CMs (77\%) stated that no rules were implemented in their areas. On the contrary, all TLs, from all districts, indicated that natural resources were managed in accordance with a set of rules. According to $73 \%$ of TLs, the rules they are implementing are ancestral rules created by previous chiefs while some (27\%) participants indicated that the current chief had created rules to address current situations. A large number (63\%) of TLs who relied on ancestral rules, stated that they were satisfied with the status quo. However, the rest indicated that they would like to change them. They mostly wanted to implement a paid permit system and increase the fine money to reduce illegal harvesting.

The use of traditional rules as part of a broader suite of management rules has also been reported in South Africa (Rankoana 2016; Constant and Tshisikhawe 2018) and in other African countries, such as Tanzania (Kangalawe et al. 2014) and Kenya (Monica et al. 2016). Rasethe et al. (2013) attest to the use of ancestral rules that are passed on from generation to generation. Chigwata (2016) also reported that in communal areas of Zimbabwe, rules and decisions related to management of natural resources are taken during meetings by current leaders (chiefs). Creating rules based on current situations helps in managing natural resources and enriches the knowledge base.

Traditional leaders, CMs and THPs who acknowledged the implementation of traditional rules, highlighted local rules that were common amongst the five districts in the Limpopo Province. In general, the most common traditional rule cited by the study participants was to not cut green plants. The collection of only small quantities was another commonly known rule amongst participants. Other common rules included seasonal collection and collecting under permit. "Closed access", "cultivation at home" and "refilling of hole after harvesting" were the least mentioned management rules in this study (Table 3). 
Table 3. Traditional rules for managing plant utilization in the five districts of Limpopo Province, South Africa, as according to a total of $263(78,98 \%)$ study participants who acknowledged the existence of traditional rules

\begin{tabular}{|c|c|c|c|c|c|c|c|c|c|c|c|c|c|c|c|c|c|}
\hline \multirow{3}{*}{$\begin{array}{l}\text { Traditional rules cited } \\
\text { by study participants }\end{array}$} & \multicolumn{3}{|c|}{$\begin{array}{c}\text { Capricorn } \\
\text { District }\end{array}$} & \multicolumn{3}{|c|}{$\begin{array}{c}\text { Sekhukhune } \\
\text { District }\end{array}$} & \multicolumn{3}{|c|}{$\begin{array}{l}\text { Mopani } \\
\text { District } \\
\end{array}$} & \multicolumn{3}{|c|}{$\begin{array}{c}\text { Waterberg } \\
\text { District }\end{array}$} & \multirow{2}{*}{\multicolumn{3}{|c|}{$\begin{array}{l}\text { Vhembe } \\
\text { District } \\
\end{array}$}} & \multirow{3}{*}{ Total } & \multirow{3}{*}{$\%$} \\
\hline & \multicolumn{12}{|c|}{ Number of study participants (n)* } & & & & & \\
\hline & $\mathbf{C M}$ & THP & TL & $\mathbf{C M}$ & THP & TL & $\mathbf{C M}$ & THP & TL & $\mathbf{C M}$ & THP & TL & $\mathbf{C M}$ & THP & TL & & \\
\hline Small quantity collected & 5 & 8 & 3 & 8 & 13 & 2 & 1 & 7 & 0 & 0 & 4 & 3 & 0 & 2 & 0 & 56 & 18 \\
\hline Do not cut down & 3 & 1 & 0 & 3 & 1 & 0 & 2 & 10 & 2 & 0 & 0 & 2 & 0 & 0 & 4 & 28 & 9 \\
\hline Permit to collect & 1 & 7 & 2 & 6 & 8 & 4 & 0 & 9 & 0 & 0 & 0 & 0 & 0 & 3 & 2 & 42 & 13 \\
\hline Seasonal collection & 5 & 7 & 4 & 7 & 14 & 5 & 0 & 2 & 0 & 0 & 3 & 0 & 0 & 4 & 0 & 51 & 16 \\
\hline No cutting during initiation & 0 & 4 & 0 & 1 & 1 & 3 & 0 & 0 & 0 & 0 & 0 & 0 & 0 & 3 & 0 & 12 & 4 \\
\hline No cutting of green plants & 2 & 4 & 3 & 12 & 20 & 2 & 3 & 2 & 4 & 0 & 2 & 4 & 0 & 6 & 2 & 66 & 21 \\
\hline Closed access & 0 & 2 & 0 & 0 & 0 & 0 & 0 & 0 & 0 & 0 & 0 & 0 & 0 & 0 & 3 & 5 & 2 \\
\hline Cultivate at home & 0 & 0 & 0 & 0 & 0 & 0 & 0 & 0 & 0 & 0 & 1 & 0 & 0 & 0 & 0 & 1 & $<1$ \\
\hline Closing hole after & 2 & 0 & 0 & 0 & 0 & 0 & 0 & 0 & 0 & 0 & 0 & 0 & 0 & 0 & 0 & 2 & $<1$ \\
\hline
\end{tabular}

harvesting

Note: CM: Community member, THP: Traditional health practitioner, TL: Traditional leader, *This number contains an overlap of responses (one person chose more than one rule)

These results are supported by Rankoana (2016) who also found that restrictions on the cutting of live plants is common in the rural areas of Limpopo Province. Some of these traditional rules are common to other parts of South Africa (Petersen et al. 2017) and other African countries, such as Kenya (Monica et al. 2016) and Tanzania (Kangalawe et al. 2014), though different rules have been reported by other studies, especially in South Africa. In the Vhembe District, for example, collection of species, including Brackenridgea zanguebarica is allowed under the supervision of an officer from the tribal authority to ensure sustainability (Tiawoun et al. 2019). Collection of plants in general, including Alepidea amatymbica in the Eastern Cape, is done via a permit from tribal offices (Stoffersen et al. 2011). The limited use of cultivation as a management strategy was disappointing, as it is a known fact that plant propagation reduces the harvesting pressure on wild populations (Maroyi 2017). Although the traditional rules in the present study were not mentioned specifically in relation to the legally protected species selected for this study, adherence to these rules would certainly contribute to their sustainability.

According to the majority of participants $(60 \%)$ who acknowledged the existence of rules for the management of plant resources, people abide by traditional rules. Those who did not harvest in the wild stated their lack of knowledge on whether traditional rules are being followed as they do not get to observe people while harvesting in the wild. In the Vhembe District, half of the participants stated that rules are followed, while another half think the opposite is true (Figure 3). According to Stoffersen et al. (2011), conservation initiatives succeed with the cooperation of those whose land the populations are found. Therefore, the cooperation of THPs and CMs is vital for managing threatened or protected plant species in their communal land.

According to most THPs (55\%), the lawbreakers were mainly muthi (traditional medicine) traders, CMs (21\%) and THPs (18\%). Muthi traders are people who sell plant and animal materials used for both witchcraft and healing practices. Only $6 \%$ of THPs indicated that outsiders were the main lawbreakers. Interestingly, CMs indicated that the lawbreakers were chiefly themselves (45\%), while $33 \%$ of them blamed the muthi traders and $22 \%$ indicated that THPs were the main lawbreakers. Traditional leaders were also of the opinion that the main lawbreakers were muthi traders (46\%), followed by THPs (29\%), and CMs (21\%). Half of the TLs added that lawbreakers are arrested by law enforcers when found breaking the law, while another 50\% said that lawbreakers are fined a certain amount of money.

The implication of muthi traders being primarily to blame for breaking the rules was not an unexpected result. It is a widely held perception that many medicinal traders are more concerned with income generation than species' sustainability (Moeng and Potgieter 2011; Tiawoun et al. 2019). The mention of a fine for lawbreakers is similar to Igboin (2016) findings in Nigeria, where lawbreakers are required to bring a token of palm wine or oil to TLs. Illegal activities however continue in Limpopo Province in spite of the punishment meted out. This is possibly due to the socio-economic status of the offenders.

\section{Community's participation in managing plants}

In most of the districts, the majority of THPs indicated that they are not allowed to help with managing plants in their area (Figure 4). On the contrary, the majority of CMs in the Capricorn, Sekhukhune, and Mopani districts, said that they are allowed to help, which is encouraging. Excluding THPs in managing plants in their area was unexpected, because THPs are generally known to be the harvesters and holders of local knowledge of medicinal plants and one would expect that more THPs would be included in the management of plant resources (Rasethe et al. 2013). Conservation initiatives are unlikely to succeed without the cooperation of CMs on whose land the populations are found, therefore, it is encouraging to find the majority of them in some districts allowed to help in managing plants (Rankoana 2016).

Traditional leaders contradicted each other when it came to the community's involvement in management. 
Half of them indicated that the community is actively involved in managing plants in their areas, whereas the other $50 \%$ noted that the community is not involved. Those who mentioned that the community is allowed to participate in management activities, highlighted that they assist by reporting illegal harvesting (cited by $47 \%$ of TLs), overharvesting (cited by $23 \%$ of TLs), and unsustainable methods of harvesting (cited by $15 \%$ of TLs), as well as by undertaking patrols (cited by $15 \%$ of TLs). Those TLs who indicated that the community did not participate in management activities, stated that CMs are afraid of harvesters who can pose a safety risk. The finding that some TLs do not involve CMs in plant management is unsurprising since culture dictates that the land belongs to and is managed solely by tribal authorities (Musavengane and Simatele 2016). Tribal authorities are people (Chief and Induna) that serve as the local government in the rural areas due to their closeness to the people at the grassroots. The Traditional Leaders Act No 10 of 1997 also indicates that all traditional leaders have an important role in safeguarding and protecting the environment in their areas of jurisdiction.

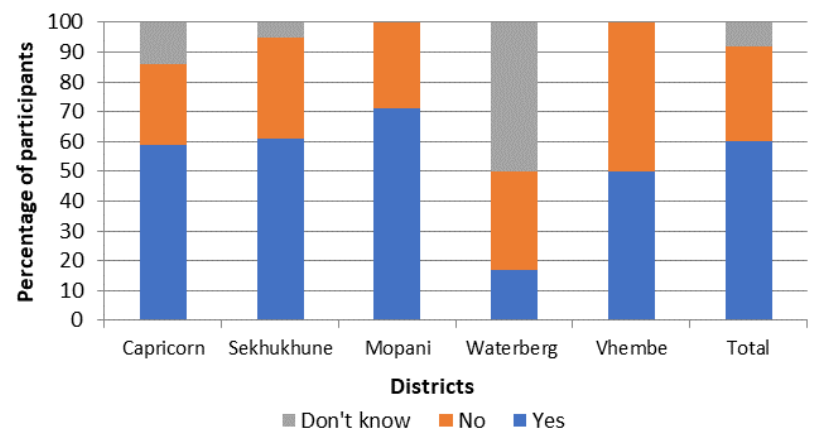

Figure 3. Perception of participants (THPs and CMs) that acknowledged there is compliance of rules implemented in the five districts of Limpopo Province, South Africa

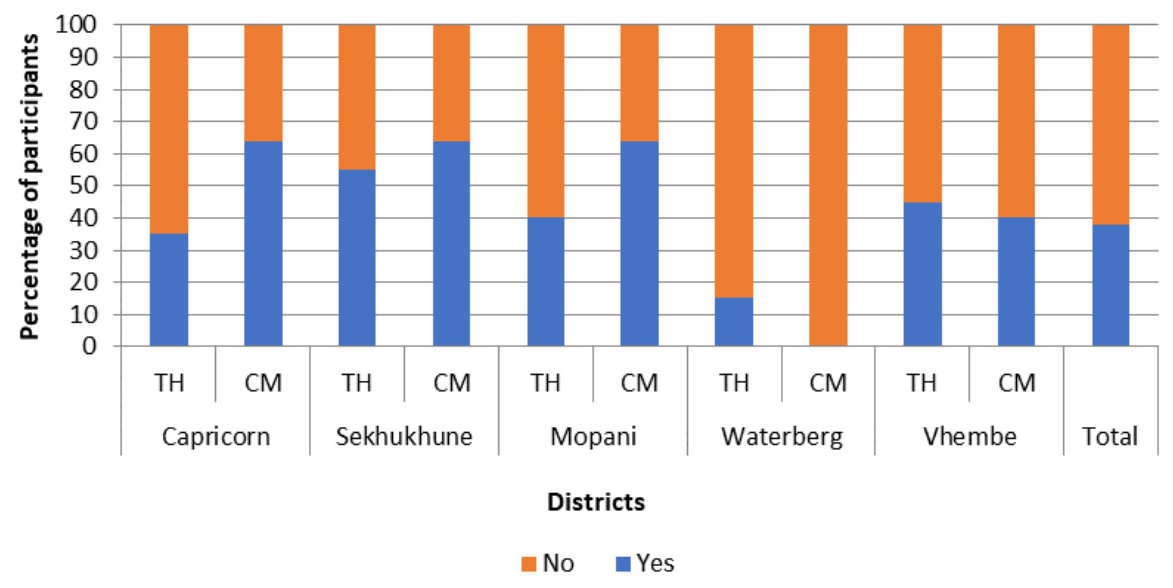

Figure 4. Responses of participants (traditional health practitioners (THPs) and community members (CMs)) when asked whether they are involved in the current management of medicinal plant resources

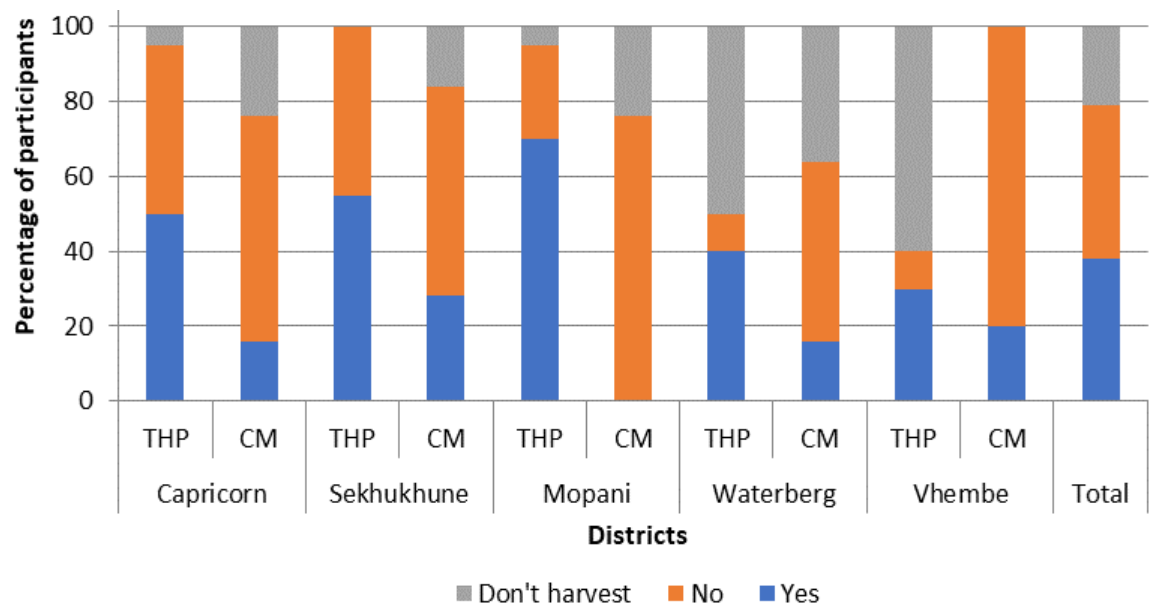

Figure 5. Study participants' responses when asked whether a permit is required to harvest plants in communal areas of the Limpopo Province, South Africa 


\section{Permit system as a management tool}

Responses to the question of whether a permit is required to harvest plants were varied, though overall the majority of study participants said 'no'. Those who indicated that a permit is not required reasoned that they do not need permission to harvest their own resources (the resources being located within their home village), and only people from outside are required to produce a permit before harvesting. Generally, more THPs indicated that they need a permit than not, which is the exact opposite for CMs (Figure 5). Though the lack of permit requirement is non-compliant with legislative provisions, it does seem to be a common understanding in South Africa as was previously reported in different provinces such as the Eastern Cape (Stoffersen et al. 2011), Limpopo (Moeng and Potgieter 2011), and the KwaZulu-Natal (Musavengane and Simatele 2016).

In general, of those study participants who understood that a permit is needed to harvest plants, more THPs than CMs mentioned that they had a permit. Overall, $71 \%$ of these THPs indicated that they had permits, $24 \%$ did not have, and $4 \%$ indicated that they only obtain permits when harvesting outside their areas. Of those THPs who claimed to have permits, $84 \%$ indicated that they were issued cards by the Traditional Healers Association (THA), which allowed them to harvest any medicinal plant wherever they wanted. Fifteen percent of THPs revealed that they acquired their permits from tribal authorities, and just $1 \%$ obtained it from government officials.

Eighty-three percent of CMs who understood the need for a permit, did not have a permit. Twelve percent of them revealed that they only get permits when harvesting outside their areas, and only 5\% of them indicated that they were currently in possession of a permit that they had obtained from tribal authorities in other areas. The issuing of permits by tribal authorities and the THA were confirmed by TLs, with about $77 \%$ of them stating that harvesters obtain permits from tribal authorities in the format of a written letter that allows them entry for a certain number of days. One of the duties of a TL is to check cards issued by the THA before allowing access to communal lands.

It is anticipated that the evasion of permit requirements will affect the local availability of species as it is likely that harvesters will collect as much material as they need without regulation of quantity. Moeng and Potgieter (2011) reports that local muthi traders are known to re-use the same permit to harvest a population to extinction, all for financial gain. Furthermore, the use of a THA card as a permit to harvest any plant species anywhere, is noncompliant with both national (NEM:BA 2004) and provincial (LEMA 2004) legislation. Species listed as threatened or protected in terms of the NEM:BA may not be harvested without a permit issued by the delegated authority (in this case the Limpopo Department of Economic Development, Environment and Tourism (LEDET). A partnership between the THA and government would empower THA leaders with respect to conservation issues, which in turn could be transferred to the THPs across the province. Since a small percentage of participants in this study mentioned that they acquired permits from tribal authorities, management of plant resources would benefit from a partnership between the government and TLs.

Local people's knowledge on protected plants and legislation

Most of the participants in all districts did not know that some of the plants they are using are protected by legislation, and more CMs than THPs did not know (Figure $6)$. The THPs who were aware indicated that they had heard it at THA meetings or from their trainers, while CMs who knew stated that they heard it on radio shows, from people around them, or from university students who had conducted studies in their area. Lack of knowledge on protected plants has been reported in the Limpopo Province before (Moeng and Potgieter 2011), and there is an apparent breakdown in communication between the local conservators and rural communities. Similar findings were reported in a study conducted by Maroyi (2017) in the Eastern Cape. It is essential that public awareness on these matters be increased.

Despite the lack of knowledge by a large majority of CMs and THPs, a majority of TLs (58\%) knew the protected status of the medicinal plants selected for this study, i.e. $40 \%$ in the Capricorn District, $40 \%$ in the Sekhukhune District, $10 \%$ in the Mopani District and all TLs from the Vhembe District. All who knew confirmed that government officials informed them. In the Capricorn and Sekhukhune Districts, TLs mentioned that they knew specifically about the protection of Warburgia salutaris, while those from the Vhembe District knew about the protection of B. zanguebarica. Surprisingly, none of the TLs from the Waterberg District were aware that these plant species are protected in legislation.

It was found that a vast majority of THPs and CMs $(97 \%)$ did not know of any of the environmental legislations they were asked about, with only a small minority $(3 \%)$ of participants indicating that they had this knowledge. Moeng and Potgieter (2011) similarly reported a widespread lack of knowledge on environmental legislation amongst Lay people.

\section{Recommended management strategies}

Community members and THPs mentioned several factors that they thought would help to improve the management of medicinal plants in their areas (Table 4). Most of them thought patrols would improve management, but patrols would have to be executed during the day and night to be successful. The enforcement of traditional rules and workshops were also among the management strategies favored by participants. Sixteen percent indicated that the use of permits could improve management.

Constant and Tshisikhawe (2018) reported that the vast majority of harvesters in some areas of the Limpopo Province overexploit the medicinal plant resources during the night to avoid patrolling officers. These management strategies are all practical and easily feasible and could be strengthened by information sharing from government agencies, such as the Department of Environment and the South African National Biodiversity Institute (SANBI). The recommended strategies are necessary to ensure the 
conservation of threatened and protected plant species in areas where they occur.

\section{Management leadership}

Twenty-eight percent of THPs and $39 \%$ of CMs interviewed in this study said that plant resources in their areas should be managed collaboratively by the chief and government (Table 5). Chief and induna was also a preferred leadership collaboration chosen by both THPs (23\%) and CM (15\%). Fifteen percent of THPs and 14\% of CMs felt that government should solely manage plants in their areas. However, other participants felt that if the government were to be given full control to manage the plants in their areas, the tribal authorities would be undermined. Several studies in South Africa have suggested collaboration between communities and government (Moeng and Potgieter 2011; Constant and Tshisikhawe 2018). If such a partnership were to be executed successfully, it would contribute immeasurably to the sustainable management of medicinal plant resources.
Ninety-five percent of TLs believed that government should intervene to improve management of medicinal plants in communal lands, thus supporting the notion that the state should collaborate with them in the management of local plant resources. Traditional leaders who wanted to partner with the government mentioned that they needed funds to appoint field patrollers (54\%), and, since they lack knowledge on conservations issues, they would also require environmental education (39\%). State assistance was also needed to strengthen traditional rules $(12 \%)$, establish nature reserves $(8 \%)$, and provide free seeds for cultivation (4\%) (Table 6). Traditional leaders opposed to government intervention thought believed that this would disrupt traditional management structures and CMs would then rebel against traditional rules, thereby upsetting the ancestors. The willingness of TLs to collaborate with the government demonstrates their desire to protect and manage plants species in their areas.

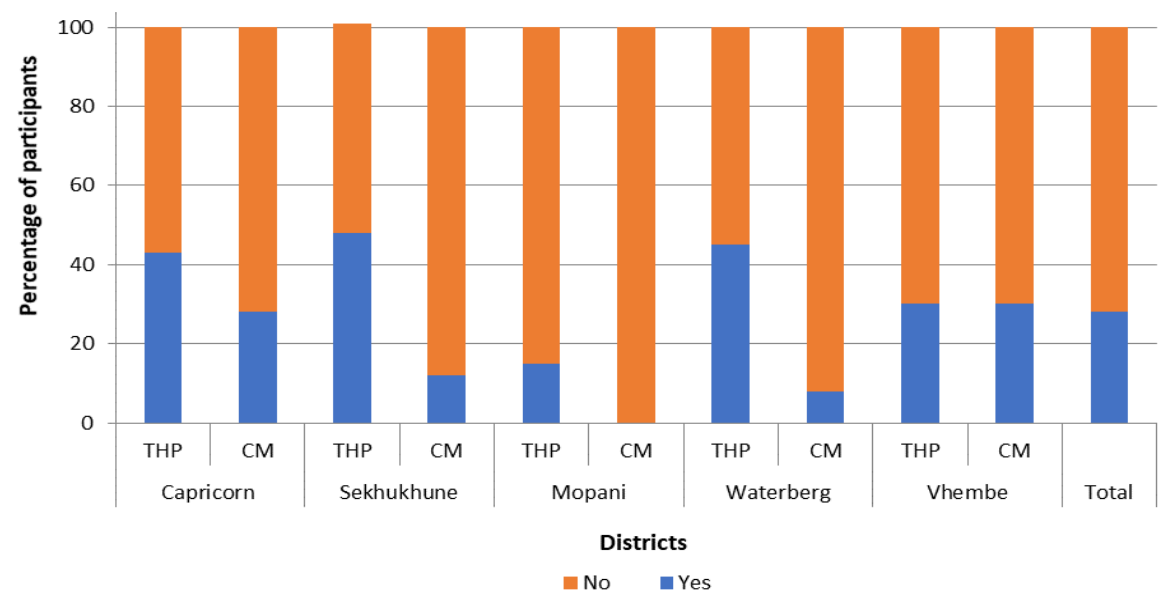

Figure 6. Responses of traditional health practitioners (THPs) and community members (CMs) in the different districts of the Limpopo Province, South Africa, to the question regarding the legal status of the plants that they are using

Table 4. Suggestions made by community members (CM) and traditional health practitioners (THP) on ways to improve management of medicinal plants in their communal areas

\begin{tabular}{|c|c|c|c|c|c|c|c|c|c|c|c|c|}
\hline \multirow[t]{2}{*}{ Strategies } & \multicolumn{2}{|c|}{$\begin{array}{c}\text { Capricorn } \\
\text { District }\end{array}$} & \multicolumn{2}{|c|}{$\begin{array}{l}\text { Sekhukhun } \\
\text { District }\end{array}$} & \multicolumn{2}{|c|}{$\begin{array}{l}\text { Mopani } \\
\text { District }\end{array}$} & \multicolumn{2}{|c|}{$\begin{array}{c}\text { Waterberg } \\
\text { District }\end{array}$} & \multicolumn{2}{|c|}{$\begin{array}{l}\text { Vhembe } \\
\text { District }\end{array}$} & \multirow{2}{*}{$\begin{array}{c}\text { Total } \\
\text { (n) }\end{array}$} & \multirow[t]{2}{*}{$\%$} \\
\hline & $\mathbf{C M}$ & THP & $\mathbf{C M}$ & THP & $\mathbf{C M}$ & THP & $\mathbf{C M}$ & THP & $\mathbf{C M}$ & THP & & \\
\hline Do patrols & 8 & 8 & 5 & 15 & 2 & 4 & 0 & 7 & 0 & 5 & 54 & 27 \\
\hline Ensure arrest of lawbreakers & 1 & 2 & 1 & 0 & 0 & 0 & 0 & 0 & 3 & 1 & 8 & 4 \\
\hline Government should intervene & 3 & 2 & 1 & 2 & 3 & 0 & 2 & 0 & 0 & 3 & 16 & 8 \\
\hline Enforce closed access & 4 & 2 & 0 & 1 & 0 & 0 & 0 & 0 & 0 & 0 & 7 & 4 \\
\hline Enforce traditional rules & 1 & 8 & 0 & 4 & 0 & 4 & 0 & 0 & 4 & 0 & 21 & 11 \\
\hline Workshops to increase knowledge & 5 & 2 & 0 & 0 & 6 & 1 & 3 & 3 & 0 & 0 & 20 & 10 \\
\hline Use permit & 4 & 6 & 3 & 7 & 2 & 0 & 0 & 3 & 0 & 6 & 31 & 16 \\
\hline Reintroduce in camps & 2 & 6 & 1 & 7 & 0 & 0 & 0 & 2 & 0 & 0 & 18 & 9 \\
\hline Free access for THP & 0 & 0 & 0 & 0 & 0 & 0 & 2 & 1 & 0 & 0 & 3 & 2 \\
\hline Quotas & 2 & 2 & 3 & 5 & 0 & 0 & 0 & 1 & 0 & 0 & 13 & 7 \\
\hline Cultivation & 0 & 2 & 2 & 0 & 0 & 0 & 0 & 0 & 0 & 0 & 4 & 2 \\
\hline
\end{tabular}

Note: THP: Traditional Health Practitioners; CM: Community Members 
Table 6. Interventions traditional leaders desire from the government to improve management of plants in their areas

\begin{tabular}{|c|c|c|c|c|c|c|c|}
\hline \multirow[t]{2}{*}{ Aspired interventions } & $\begin{array}{c}\text { Capricorn } \\
\text { District }\end{array}$ & $\begin{array}{c}\text { Sekhukhune } \\
\text { District }\end{array}$ & $\begin{array}{l}\text { Mopani } \\
\text { District }\end{array}$ & $\begin{array}{c}\text { Waterberg } \\
\text { District }\end{array}$ & $\begin{array}{l}\text { Vhembe } \\
\text { District }\end{array}$ & \multirow[t]{2}{*}{ Total } & \multirow[t]{2}{*}{$\%$} \\
\hline & \multicolumn{5}{|c|}{ Number $(n *)$ of participants } & & \\
\hline Appoint field rangers & 4 & 2 & 0 & 5 & 3 & 14 & 54 \\
\hline Workshop & 2 & 1 & 2 & 3 & 2 & 10 & 39 \\
\hline Rules/regulations & 1 & 0 & 0 & 2 & 0 & 3 & 12 \\
\hline Provide seed & 1 & 0 & 0 & 0 & 0 & 1 & 4 \\
\hline Establish nature reserve & 0 & 1 & 1 & 0 & 0 & 2 & 8 \\
\hline
\end{tabular}

Note: TL: Traditional leader, *This number contains an overlap of responses (one person chose more than one intervention)

Table 5. Leadership suggested by traditional health practitioners and community members to manage plants

\begin{tabular}{lcc}
\hline \multirow{2}{*}{ Suggested leadership } & THP & CM \\
\cline { 2 - 3 } Chief and local residents & Percentage (\%) of participants \\
\hline Chief and induna & 10 & 6 \\
Chief and government & 23 & 15 \\
Chief & 28 & 39 \\
Government & 8 & 18 \\
Local residents & 15 & 14 \\
Do not know & 6 & 3 \\
Nobody & 11 & 4 \\
\hline
\end{tabular}

Note: THP: Traditional Health Practitioners, CM: Community Members *This number contains an overlap of responses (one person chose more than one leadership)

\section{Management of plants by conservation officers (Top-up approach)}

The implementation of environmental legislation to manage plants

Conservation officers (COs) were asked about the legislation they use to manage medicinal plants. Forty-five percent and $22 \%$ of them correctly mentioned using NEM:BA (national legislation) and LEMA (provincial legislation), respectively, but 33\% said they did not know which legislation they should use. This unfortunate lack of knowledge among a third of the officials is a concern because failure to enforce these legislations contributes to the increasing unsustainable harvesting of important plants. Furthermore, as the implementation of environmental legislation is one of the shared responsibilities between national and provincial governments, fragmented implementation has affected the capacity of officials at both levels (Van Wyk and Prinsloo 2018). Almost 30\% of COs prohibited the harvest of $B$. zanguebarica, particularly those interviewed in the Capricorn and Vhembe districts. The harvest of Siphonochilus aethiopicus was prohibited by COs in the Capricorn District. This is evidence of a lack of alignment in the management of these species across the province. Poor implementation of environmental legislation will render most threatened plant species extinct.

\section{Patrols as a management strategy}

Conservation officers indicated that their main management strategy involves enforcement of the law through patrolling. Those $(36 \%)$ who indicated that they knew the TOPS-listed plant species that were the focus of this study mentioned that they patrol and inspect communal areas in order to prevent the harvest of these species. Others (64\%) who did not know the species mentioned they only do patrols to regulate the harvest of fuelwood species. The most common reason for not patrolling was that they only respond to complaints, while some mentioned that they are old and are no longer fit enough for patrolling. Strydom and King (2013) supported this finding that implementation of conservation laws is limited by the government's willingness and ability to act against those who fail to comply with the law.

Most of the officials interviewed (60\%) said that they inspect muthi shops to see whether protected species are being sold (Figure 7). Furthermore, mentioned that they also check for trading permits. All officials in the Mopani and Vhembe districts, and $67 \%$ and $33 \%$ of COs in the Capricorn and Sekhukhune Districts, respectively, indicated that they inspect muthi shops, while inspections of them muthi shops are not taking place in the Waterberg District at all. Of the COs who conduct patrols, $80 \%$ of them consider the muthi traders to be the main lawbreakers, but the other $20 \%$ thought that the THPs were the main lawbreakers. Those who did not inspect muthi shops reasoned that most plants in muthi shops are already processed or are traded as parts (e.g. roots) which are impossible or not easy to identify. This indeed is a major challenge that is yet to be solved. Therefore, it is of great importance that these officers be informed that DNA barcoding can be used to identify parts and derivatives of various threatened species that may be sold at muthi shops. DNA barcoding was successfully used to expose illegal trading of threatened species sold at traditional markets in the KwaZulu-Natal and Gauteng Provinces of South Africa (Williamson et al. 2016).

\section{Major problems encountered in managing plants}

When asked why they do not inspect or undertake patrols, most COs indicated that their main challenges include limited resources (staff and vehicles) and lack of knowledge on the plants (species identification in the field and their distributions) (Figure 8). The majority of COs indicated that there are 10 officials responsible for conducting patrols and inspections in their districts, while $40 \%$ of them mentioned that there are less than five officials in the district. Sixty percent of COs rely on the user's knowledge to identify plants during patrols or inspections. 




Figure 7. Conservation officers (COs) response to whether they patrol muthi shops

Thirty-four percent of the officials indicated that they use traditional knowledge to identify the plants since they are themselves familiar with them, while $6 \%$ of them sometimes conduct patrols and inspections with botanists who help to identify plants, especially in muthi shops. Officials in the Vhembe district are mostly females (60\%) where it was mentioned that patrols/inspections are not conducted due to safety concerns. Two officials in the Vhembe District also indicated that their working hours limit the effectiveness of patrols, since $B$. zanguebarica is culturally collected at night. Many officials are too old to be actively involved in inspections and patrols.

Similar findings were highlighted by Moeng and Potgieter (2011) on limited resources and lack of knowledge as limiting factors for proper management, also for the Limpopo Province. Constant and Tshisikhawe (2018) documented that this plant is harvested in the dark by a naked person to avoid being seen by passers-by; this is believed to be adhered to by people from the area. Capacitating these officials through appropriate training is essential.

In conclusion, the majority of participants across most districts reported that no one is managing plant resources in their communal lands. The threatened or protected plant species investigated in this study might face local extinction through overexploitation. However, the general traditional rules that are used in some of the areas are vital to ensure the survival of all utilized plants within the area. The participants' perceptions that government plays a minor role in the management and regulation of these plant species is indicative of a lack of communication between COs and local people. Therefore, it is understandable that most of the interviewed people (CMs, THPs, and TLs) were not aware of the conservation status of the species investigated in this study nor did they have any knowledge on the legislation regulating these species. There are provincial conservation officials who lack knowledge on legislation and cannot identify specimens of these species, which was unexpected and of great concern.

Based on the current research, key recommendations are: (i) Collaborative partnerships should be established

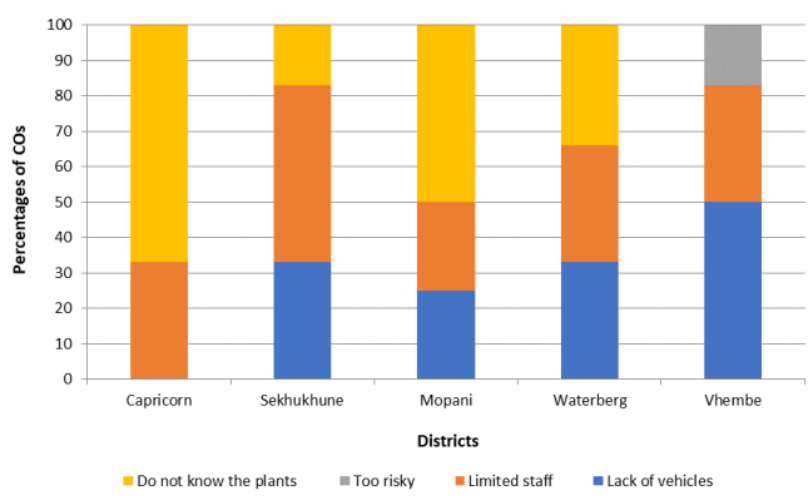

Figure 8. Problems encountered by conservation officials (COs) in relation to managing plants in the surveyed districts of the Limpopo Province, South Africa

between the government and TLs in relation to managing TOPS-listed plant species in communal lands. (ii) Workshops should be conducted with the THPs, CMs, and TLs to raise awareness amongst members in relation to legislation and permitting requirements. (iii) Provincial COs should be capacitated in relation to legislation and the identification of legally protected plant species. (iv) DNA barcoding should be conducted for TOPS-listed medicinal plant species to aid in the identification of parts and derivatives in muthi shops.

\section{ACKNOWLEDGEMENTS}

The South African National Biodiversity Institute (SANBI) supported and funded this project and carried out through the University of Limpopo, South Africa. We owe a depth of gratitude to the communities who participated in this study.

\section{REFERENCES}

Chigwata T. 2016. The role of traditional leaders in Zimbabwe: are they still relevant? Law Democr Dev 20 (1): 69-90 DOI: 10.4314/ldd.v20i1.4.

Constant NL, Tshisikhawe MP. 2018. Hierarchies of knowledge: ethnobotanical knowledge, practices and beliefs of the Vhavenda in South Africa for biodiversity conservation. J Ethnobiol Ethnomed 14 (1): 1-28. DOI: 10.1186/s13002-018-0255-2.

Coopoosamy RM, Naidoo KK. 2012. An ethnobotanical study of medicinal plants used by traditional healers in Durban, South Africa. Afr J Pharmacy Pharmacol 6 (11): 818-823. DOI: 10.5897/AJPP1 1.700

FAO. 2016. Effect of Human Activity on Biodiversity. Food and Agricultural Organisation of the United Nations, Rome.

Gill P, Stewart K, Treasure E, Chadwick B. 2008. Methods of data collection in qualitative research: interviews and focus groups. $\mathrm{Br}$ Dent J 204 (6): 291-295. DOI: 10.1038/bdj.2008.192.

Igboin BO. 2016. Traditional leadership and corruption in pre-colonial Africa: how the past affects the present. Studia Hist Ecc 42 (3): 142160. DOI: $10.17159 / 2412-4265 / 2016 / 228$.

Kangalawe RY, Noe C, Tungaraza FS, Naimani G, Mlele M. 2014. Understanding of traditional knowledge and indigenous institutions on sustainable land management in Kilimanjaro region, Tanzania. Open J Soil Sci 4: 469-493. DOI: 10.4236/ojss.2014.413046. 
Kaoma H, Shackleton CM. 2015. The direct-use value of urban tree nontimber forest products to household income in poorer suburbs in South African towns. For Policy Econ 61: 104-112. DOI: 10.1016/j.forpol.2015.08.005.

Khadka C, Vacik H. 2012. Comparing a top-down and bottom-up approach in the identification of criteria and indicators for sustainable community forest management in Nepal. Int J For Res 85 (1): 145158. DOI: $10.1093 /$ forestry/cpr068.

LEMA No.7 of 2004. Provincial Gazette, Limpopo Province. South Africa.

Maroyi A. 2013. Warburgia salutaris (Bertol f) Chiov: A multi-use ethnomedicinal plant species. J Med Plant Res 7 (2): 53-60. DOI: 10.5897/JMPR.9001291.

Maroyi A. 2017. Diversity of use and local knowledge of wild and cultivated plants in the Eastern Cape province, South Africa. J Ethnobiol Ethnomed 13 (1): 1-16. DOI: 10.1186/s13002-017-0173-8.

Moeng ET, Potgieter MJ. 2011. The trade of medicinal plants by muth shops and street vendors in the Limpopo Province, South Africa. J Med Plant Res 5 (4): 588-564.

Monica KC, Mark K, Paul O. 2016. Traditional controls of harvesting and conserving medicinal plants in Keiyo south Sub-County, Kenya. Int J Humanit Soc Sci 6 (11): 54-63.

Mucina L, Rutherford MC. 2006. The Vegetation of South Africa, Lesotho and Swaziland. Strelizia 19, South African National Biodiversity Institute, Pretoria.

Musavengane R, Simatele DM. 2016. Community-based natural resource management: the role of social capital in collaborative environmental management of tribal resources in KwaZulu-Natal, South Africa. Dev South Afr 33 (6): 806-821. DOI: 10.1080/0376835X.2016.1231054

Neto EMF, Peroni N, Albuquerque UP. 2010. Traditional knowledge and management of umbu (Spondias tuberosa, Anacardiaceae): an endemic species from semi-arid region of north-eastern Brazil. Econ Bot 64 (1): 11-21. DOI: 10.1007/s12231-009-9106-3.

NEM:BA No 107 of 2004. Government Gazette. Cape Town, South Africa.

Pérez-Vicente S, Ruiz ME. 2009. Descriptive statistics. Allergol Immunopathol 37: 314-320. DOI: 10.1016/j.aller.2009.10.005.
Petersen L, Reid AM, Moll EJ, Hockings MT. 2017. Perspectives of wild medicine harvesters from Cape Town, South Africa. S Afr J Sci 113 (9-10): 1-8. DOI: 10.17159/sajs.2017/20160260

Rankoana SA. 2016. Sustainable use and management of indigenous plant resources: A case of Mantheding Community in Limpopo Province, South Africa. Sustainability 8 (3): 221. DOI: 10.3390/su8030221.

Rasethe MT, Semenya SS, Potgieter MJ, Maroyi A. 2013. The utilization and management of plant resources in rural areas of the Limpopo Province, South Africa. J Ethnobiol Ethnomed 9 (1): 1-8. DOI: 10.1186/1746-4269-9-27.

Semenya SS, Mokgoebo MJ. 2020. The Utilization and Conservation of Indigenous Wild Plant Resources in the Limpopo Province, South Africa. Natural Resources Management and Biological Sciences. Intech open, UK. DOI: 10.5772/intechopen.89920.

SANBI. 2020. Statistics: Red List of South African Plants version 2020.1. South African National Biodiversity Institute, Silverton, SA. Downloaded from Redlist.sanbi.org on 2021/08/17.

Stoffersen A, Winstrup M, Nieminen R, Allerton T. 2011. Medicinal Plants and Traditional Healing in Contemporary Rural South Africa: The sustainability of medicinal plant use in the local culture in Ongeluksnek, Eastern Cape, South Africa. [Thesis]. University of Copenhagen, Denmark.

Strydom HA, King ND. 2013. Fuggle and Rabie's Environmental Management, Second edition. Juta, Claremont, Cape Town.

Tiawoun MAP, Tshisikhawe MP, Gwata ET. 2019. Investigation of current threats to the existence of Brackenridgea zanguebarica in a small geographic area in Vhembe, Limpopo Province, South Africa. Biodiversitas 20 (6): 1487-1495. DOI: 10.13057/biodiv/d200601.

Van Wyk AS, Prinsloo G. 2018. Medicinal plant harvesting, sustainability and cultivation in South Africa. Biol Conserv 227: 335-342. DOI: 10.1016/j.jep.2015.10.031

Van Wyk BE. 2015. A review of commercially important African medicinal plants. J Ethnopharmacol 176: 118-34. DOI: 10.1016/j.jep.2015.10.031.

Williamson J, Maurin O, Shiba SNS, Van der Bank H, Pfab M, Pilusa M, Kabongo RM, van der Bank M. 2016. Exposing the illegal trade in cycad species (Cycadophyta: Encephalartos) at two traditional medicine markets in South Africa using DNA barcoding. Genome 59 (9): 771-781. DOI: 10.1139/gen-2016-0032. 